\title{
Stocks and exploitation of East African blackwood Dalbergia melanoxylon: a flagship species for Tanzania's miombo woodlands?
}

Stephen M. J. Ball

\begin{abstract}
East African blackwood is the common name for Dalbergia melanoxylon, the most valuable timber growing in the miombo woodlands of southern Tanzania, and a potential flagship species to justify conservation of this habitat. The population density, structure and exploitation of this economically and socially important species were studied in an area of southern Tanzania. Harvestable timber was found at a density of $1.03 \mathrm{~m}^{3} \mathrm{ha}^{-1}$. Multi-stemmed trees, which have a lower marketable value, were more frequent in burned
\end{abstract}

areas. Local people have a number of uses for the species but have replacements for all but its medicinal application. Felling licence and export figures are inconsistent but suggest that illegal harvesting is occurring. The implications of these results for the species' flagship status and options for community-based management are discussed.

Keywords Blackwood, Dalbergia melanoxylon, flagship species, miombo woodlands, Tanzania.

\section{Introduction}

Flagship species are an important conservation tool because they can be used to reach out to the general public and raise funds (Bowen-Jones \& Entwistle, 2002). Often they are used to support conservation activities in and around existing protected areas, many of which, particularly in Africa, were first established because they had large populations of charismatic megafauna. However as conservation has moved towards engagement with local communities these mammalian flagship species have become as much a hindrance as a help because of conflicts between people and animals (Haule et al., 2002). Moreover, protected areas do not always cover the areas of greatest biodiversity and can create conservation islands in a sea of degraded habitat (Williams et al., 2000). An approach is needed that can attract funds to land outside the protected areas system and find flagship species with a broad appeal.

East African blackwood is the common name for Dalbergia melanoxylon (Family Leguminosae, known as mpingo in Swahili). It is a small, many-branched tree rarely exceeding $10 \mathrm{~m}$ in height and with a bole circumference normally $<120 \mathrm{~cm}$ (Lovett, 1988). It is known to fix nitrogen and grows in an ecosystem that usually has poor soils (Högberg, 1986), but otherwise its ecological importance is unknown. The tree gets its name from

Stephen M.J. Ball Mpingo Conservation Project, c/o Fauna \& Flora International, Great Eastern House, Tenison Road, Cambridge CB1 2TT, UK. E-mail steve.ball@mpingoconservation.org

Received 4 April 2003. Revision requested 4 September 2003 Accepted 26 November 2003. the dark-coloured heartwood that in the best quality timber is inky black and can reach densities of $1.1 \mathrm{~g} \mathrm{~cm}^{-3}$ (Malimbwi et al., 2000). Estimates for the time taken for blackwood to reach timber size vary widely; 70-100 years is the figure quoted most often (Gregory et al., 1999).

The heartwood from top quality blackwood is one of the most expensive timbers in the world, with billets selling for up to US $\$ 18,000$ per cubic metre (Jenkins et al., 2002). Along with Diospyros spp., blackwood is the most expensive timber to fell in Tanzania; licences cost TSh 70,000 (US \$70) per cubic metre of logs (Jenkins et al., 2002). The wood is exported for the manufacture of clarinets, oboes, bagpipes and other musical instruments. Locally it is used for traditional carvings, and for a variety of domestic purposes. In the Far East it is used for parquet flooring (Jenkins et al., 2002). The tree's small size causes problems for sawmills, exacerbated by the wood's tendency to exhibit bends, lateral twists, deep fluting, heart rot, knots and other faults (Lovett, 1987). Thus it can be extremely difficult to find straight, faultless sections suitable for making exportable billets; any defects in the timber will cause it to split on the lathe. As a consequence the sawmills generate large amounts of waste; recovery rates are c. 9\% (Gregory et al., 1999). Official annual exports of processed billets from Tanzania averaged $42 \mathrm{~m}^{3}$ for the period 1980-91 (Marshall, 1995).

Blackwood is Tanzania's national tree. Although it has a much wider distribution, it is only in East Africa that the tree reaches harvestable size in sufficient abundance for it to be a commercial proposition. In recent years Kenya's stocks have been completely exhausted, such 
that carvers there must now obtain their wood from Tanzania (Cunningham, 1998), and today most blackwood comes from Mozambique and southern Tanzania. Until recently this area of Tanzania was one of the poorest and remoter parts of the country, cut off when the Rufiji River flooded every wet season (Gregory et al., 1999). Poor infrastructure has hitherto served to protect the region's woodlands, and its estimated 70\% forest cover (District Executive Officer, Kilwa, 1998, pers. comm.) is substantially higher than the national average. This is about to change, with a new bridge across the Rufiji completed in 2002 and subsequent upgrading of the roads.

Blackwood is able to grow in a variety of conditions (Nshubemuki, 1994), but most of Tanzania's stocks are found in open miombo woodlands. Blackwood from the coastal strip has a reputation for poor quality (the heartwood is often comparatively brown in colour), and sawmills prefer to source their wood from inland (Gregory et al., 1999). The miombo ecosystem that covers most of southern Tanzania extends to Angola in the west and Mozambique in the south, and constitutes the single largest vegetation type in East Africa (Campbell et al., 1996). Miombo is estimated to have c. 8,500 species of plants of which c. $54 \%$ are endemic (White, 1983), and is characterized by dominant trees in the genera Brachystegia, Julbernardia and Isoberlinia (Desanker et al., 1997); blackwood is an understorey species.

Conservation interest in blackwood has grown since the mid 1980s when the United Nations Environment Programme established the Don't Stop the Music project focused on the species, but this was soon abandoned. In 1991 Fauna \& Flora International launched the SoundWood programme (SoundWood, 2004) aimed at conserving all trees used to make musical instruments, and blackwood was designated a key focal species. In 1994 a proposal was submitted for listing blackwood under CITES Appendix II, but was subsequently withdrawn to allow for further consultations. Blackwood was also the subject of the 1992 BBC Wildlife film The Tree That Makes Music, which lead to the founding of the African Blackwood Conservation Project (ABCP, 2004).

Here I describe the distribution and harvestable value of blackwood to be found in one locality in southern Tanzania. I describe the relationship that local people have to the species and consider some of the threats to the commercial future of blackwood. I show that blackwood meets the criteria advanced by Bowen-Jones \& Entwistle (2002) for a flagship species, and argue that blackwood should be seen as an important species for conservation in the region, one that presents an excellent opportunity for conservation integrated with local development needs.

\section{Methods}

Surveys were conducted around Migeregere village in southern Tanzania during the 1998 dry season. Migeregere, with substantial blackwood stocks in the vicinity, is located at approximately $8^{\circ} 52^{\prime} \mathrm{S} 39^{\circ} 15^{\prime} \mathrm{E}$, c. $30 \mathrm{~km}$ inland from Kilwa, the district administrative centre, and $200 \mathrm{~km}$ south of Dar es Salaam. An area of miombo woodland to the east of Migeregere village between the $250 \mathrm{ft}(76 \mathrm{~m})$ and $500 \mathrm{ft}(152 \mathrm{~m})$ contours and covering $150 \mathrm{~km}^{2}$ was surveyed (contour heights were in feet as the only available maps date from 1967). Half of the survey plots were located inside nearby Mitarure Forest Reserve and half outside, but I found little to differentiate the reserve from the surrounding area.

A total of 101 plots of $20 \mathrm{~m}$ fixed radius were used to sample the study area. They were located randomly within the study site stratified into three categories: unburned, burned (since the end of the wet season), and riverine (including an ephemeral water course). Inside each sample plot all stems (distinct at breast height) of blackwood trees were counted and their girth measured, along with tree height and canopy area. The greatest straight length of stem free from obvious defects (ESL) was estimated to the nearest half metre.

A simple cylinder shape was assumed for calculation of the estimated straight volume (ESV) of each tree. This is reasonable because the observable taper was usually small $(<10 \%)$. ESV provides an estimated volume over-bark (on which licence fees are based) for the most valuable part of the tree and, except for relatively large trees, the only part likely to ever reach a sawmill. Inspections of sawmills in Lindi region revealed that most logs were at least $70 \mathrm{~cm}$ long and had a diameter of $22 \mathrm{~cm}$ or more, and hence I denoted as harvestable trees with a straight section larger than this. From this I calculated the harvestable worth (HW) for each tree, which is zero if it is not harvestable, and equals the ESV if it is.

Blackwood juveniles (defined as circumference at breast height $<10 \mathrm{~cm}$ ) were counted within a $2 \mathrm{~m}$ radius sub-plot. One sub-plot for each full-sized plot was centred on the closest blackwood juvenile to the centre of the main plot. If no blackwood juveniles were present, then the closest juvenile of any species was used, otherwise the sub-plot was situated at the centre of the main plot. Canopy cover was estimated over a $5 \mathrm{~m}$ radius circle from the centre of the sub-plot.

The knowledge and attitudes of local people towards blackwood were investigated in a series of meetings with six groups, stratified by age and gender, from Migeregere and the nearby sub-village of Mbate. A series of open-ended questions about local uses and harvesting practices were put to each group and discussions allowed to develop. In addition I obtained data on 
harvesting and licences from the District Forestry Office in Kilwa, and visited the sawmills at Kilwa and Ikwiriri.

\section{Results}

The overall distribution of blackwood was patchy, with adult trees found in $40 \%$ of plots at a mean density of 8.5 trees $\mathrm{ha}^{-1}$. The greatest number of trees found in a single plot was 11, which corresponds to a density of 87.5 trees $\mathrm{ha}^{-1}$. There was no significant variation by plot type (burned / unburned / riverine; $\mathrm{F}=2.11$, $\mathrm{df}=2,98, \mathrm{P}>0.1$ ). It is commonly believed amongst local people and foresters that blackwood tends to grow in clusters, and evidence for this can be seen in the probability of finding further blackwood in a plot that rose from 40 to $78 \%$ in plots with at least one blackwood tree $(\mathrm{P}<0.001$, binomial test, $\mathrm{n}=101)$.

Blackwood is frequently multi-stemmed and there was a marked increase in the average number of stems per tree in burned plots (1.9 per tree) compared to unburned plots (1.1) and riverine plots (1.2) $(\mathrm{F}=5.69, \mathrm{df}=2,105$, $\mathrm{P}<0.01)$. Trees in burned plots were more likely to have more than one stem $(39 \%)$ than in unburned or riverine plots $(9 \%)(\mathrm{P}<0.01$, binomial test, $\mathrm{n}=108)$. Mean stem diameter at breast height $(\mathrm{DBH})$ was $22 \mathrm{~cm}$, height $8.9 \mathrm{~m}$ and canopy area $25 \mathrm{~m}^{2}$. The tallest tree surveyed was $19 \mathrm{~m}$ and the thickest seen had a DBH of $68.4 \mathrm{~cm}$.

The mean ESL was $2.0 \mathrm{~m}(\max 8 \mathrm{~m})$, and the mean ESV $0.126 \mathrm{~m}^{3}$. Eighty-two percent of blackwood trees surveyed satisfied the minimum straight length condition for harvesting, something that is unlikely to change as trees grow. These potentially harvestable trees occurred at a density of $7.0 \mathrm{ha}^{-1}$. Fifty percent of the complete sample satisfied both conditions for harvestability (i.e. with a length of at least $70 \mathrm{~cm}$ and a diameter of at least $22 \mathrm{~cm}$ ), and were found at a density of $4.2 \mathrm{ha}^{-1}$. These trees had a mean ESV of $0.163 \mathrm{~m}^{3}$. Table 1 summarizes the variations in harvestability and mean harvestable worth by plot type. Harvestable worth does not significantly vary by plot type either when analysed on a per tree basis $(\mathrm{F}=1.37, \mathrm{df}=2,105, \mathrm{P}>0.1)$ or on a per plot basis $(\mathrm{F}=0.398, \mathrm{df}=2,98, \mathrm{P}>0.1)$.

Thirty percent of plots contained juvenile blackwood, with seedlings and saplings (the latter defined as $50 \mathrm{~cm}$ or greater in height, or with a circumference $>1 \mathrm{~cm}$ at $20 \mathrm{~cm}$ above ground) in approximately equal numbers. There was no relationship between presence of adult and juvenile blackwood $\left(\chi^{2}=1.28, \mathrm{df}=1, \mathrm{P}>0.1\right)$. In total $52 \%$ of plots contained live blackwood of any age. Juvenile presence did not vary significantly between plot types, but juveniles were much more common $\left(\chi^{2}=8.76\right.$, $\mathrm{df}=1, \mathrm{P}<0.01)$ in sub-plots where the surrounding $5 \mathrm{~m}$ sub-plot had $40 \%$ canopy cover or less $(44 \%$ blackwood juvenile presence) compared with shadier plots (20\%). This compares with a c. $86 \%$ frequency for juveniles of any species regardless of canopy cover in a $5 \mathrm{~m}$ radius.

Blackwood is turned to a variety of uses by local people, and many of these have been previously documented (e.g. Lewis \& Berry, 1988). The following uses for the tree were all mentioned by people at Migeregere: building materials, charcoal, firewood, furniture (stools and toilet seats were given as specific examples, but the implication was of wider use), household implements (combs, cups, plates, maize pounders, chapati rolling boards), and medicine (a pulp of the leaves is fed to babies to promote strong growth). Everyone at Migeregere agreed that blackwood makes the best charcoal, although the difficulty in felling it often deters people. A similar problem affects use of blackwood for firewood, although women (the main collectors of firewood for domestic purposes) also said that the flame is too hot and burns through the bottom of their pots (Moore \& Hall, 1987, reported the same result). They were all aware that carvers use blackwood, but there was widespread ignorance of its use in musical instruments. For virtually all uses at least one group of interviewees listed blackwood as one of the preferred species for that purpose, but in all cases there were equally good alternatives.

Table 1 Variations in density and harvestable worth of blackwood trees by plot type.

\begin{tabular}{llllllll}
\hline Plot type & $\begin{array}{l}\text { \% trees with } \\
\mathrm{ESL}^{1} \geq 1 \mathrm{~m}\end{array}$ & $\begin{array}{l}\text { Density of trees with } \\
\mathrm{ESL}^{1} \geq 1 \mathrm{~m}\left(\mathrm{ha}^{-1}\right)\end{array}$ & $\begin{array}{l}\text { Mean ESV } \\
\text { per tree }\left(\mathrm{m}^{3}\right)\end{array}$ & $\begin{array}{l}\text { Density of } \\
\text { harvestable }\end{array}$ & $\begin{array}{l}\text { harvestable } \\
\text { hasees }\left(\mathrm{ha}^{-1}\right)\end{array}$ & $\begin{array}{l}\text { Mean } \mathrm{HW}^{4} \\
\text { per tree }\left(\mathrm{m}^{3}\right)\end{array}$ & $\begin{array}{l}\mathrm{Mean} \mathrm{HW}^{4} \\
\left(\mathrm{~m}^{3} \mathrm{ha}^{-1}\right)\end{array}$ \\
\hline Unburned & 89 & 3.9 & 0.182 & 78 & 3.4 & 0.175 & 0.76 \\
Burned & 73 & 7.7 & 0.107 & 47 & 5.0 & 0.095 & 1.12 \\
Riverine & 92 & 9.5 & 0.125 & 39 & 4.1 & 0.112 & 1.20 \\
All & 82 & 7.0 & 0.126 & 50 & 4.2 & 0.114 & 1.03 \\
\hline
\end{tabular}

${ }^{1}$ ESL, estimated straight length (see text for details).

${ }^{2} \mathrm{ESV}$, estimated straight volume (see text for details).

${ }^{3}$ Fulfilling minimum length and diameter requirements (see text for details).

${ }^{4} \mathrm{HW}$, harvestable worth (see text for details). 
The wages received by local people for assisting commercial loggers was given by male interviewees as the most important 'use', for them, of blackwood. There was some confusion, perhaps attributable to the relative rarity of such events, over when this normally occurred, although this could be just a symptom of a wider indifference towards such matters. The dry months of May-September are the most suitable for logging and four out of six groups questioned gave an answer that was at least partially consistent with this. The Ikwiriri sawmill closes during the wet season. Sawmills expressed a preference for logs with a circumference of $>1 \mathrm{~m}$, and a length of $75 \mathrm{~cm}$ or more, but I saw many smaller logs. One sawmill yard contained a log with a circumference of only $28 \mathrm{~cm}$, and $54 \%$ of logs were smaller than the manager's declared minimum.

Fig. 1 shows the official figures for blackwood harvesting in Kilwa District, but these are not corroborated by other sources. The sawmill in Kilwa claimed they harvested $200 \mathrm{~m}^{3}$ of blackwood in 1986-7, and then nothing else until 1994, when they felled another $130 \mathrm{~m}^{3}$, and the large peak over 1988-89 is not reflected in the export figures reported by Marshall (1995).

Moore \& Hall (1987) believed that probably c. $50 \%$ of blackwood is felled illegally. The foresters at Kilwa, in agreement with other districts in Lindi Region, did not think illegal harvesting was a major problem in the district, and that shifting cultivation and land clearance were bigger threats to blackwood. In contrast sawmill owners spoke of their knowledge of illegal felling (although all denied they were involved). There are about 15 carvers based around Nangurukuru, between Kilwa and Migeregere, but their impact on local stocks is likely to be low compared with the sawmills. As smaller operations, they are perhaps more likely to locate and fell single trees, although they said they were currently exploiting a small cluster of trees.

Felling in forest reserves requires a special permit from the central government. Between 1985 and 1991 permits were granted for Mitarure Forest Reserve. All of the district's blackwood harvested between February 1987 and August $1988\left(641.5 \mathrm{~m}^{3}\right)$ came from the Reserve, as did a further $23.5 \mathrm{~m}^{3}$ in the years 1991-2. The reserve provided the bulk of all species felled in the district between 1985 and 1991, but relatively little since. The men at Mbate, which is on the border of the Forest Reserve, knew of government restrictions on the felling of certain trees in the reserve, mentioning blackwood, Pterocarpus angolensis, Milicia excelsa and Khaya nyasica as species to which these regulations applied. There was some encroachment evident at Mbate (the local people thought the boundary, which is not visibly marked, was some distance further inland) but the district forestry officer did not see this as a major problem. Regular burning was evident throughout the reserve, and there was little to distinguish the reserve from the land outside it.

\section{Discussion}

Migeregere is the only place in Lindi region where significant stocks of blackwood are evident from the road (Gregory et al., 1999), and yet my estimates for mean estimated straight volume and harvestable worth are substantially below the only other available figures. Puhakka (1991), analysing licence data from Mtwara District between January and October 1990, implied an average estimated straight volume of $0.410 \mathrm{~m}^{3}$ per tree, while Malimbwi et al. computed a mean harvestable

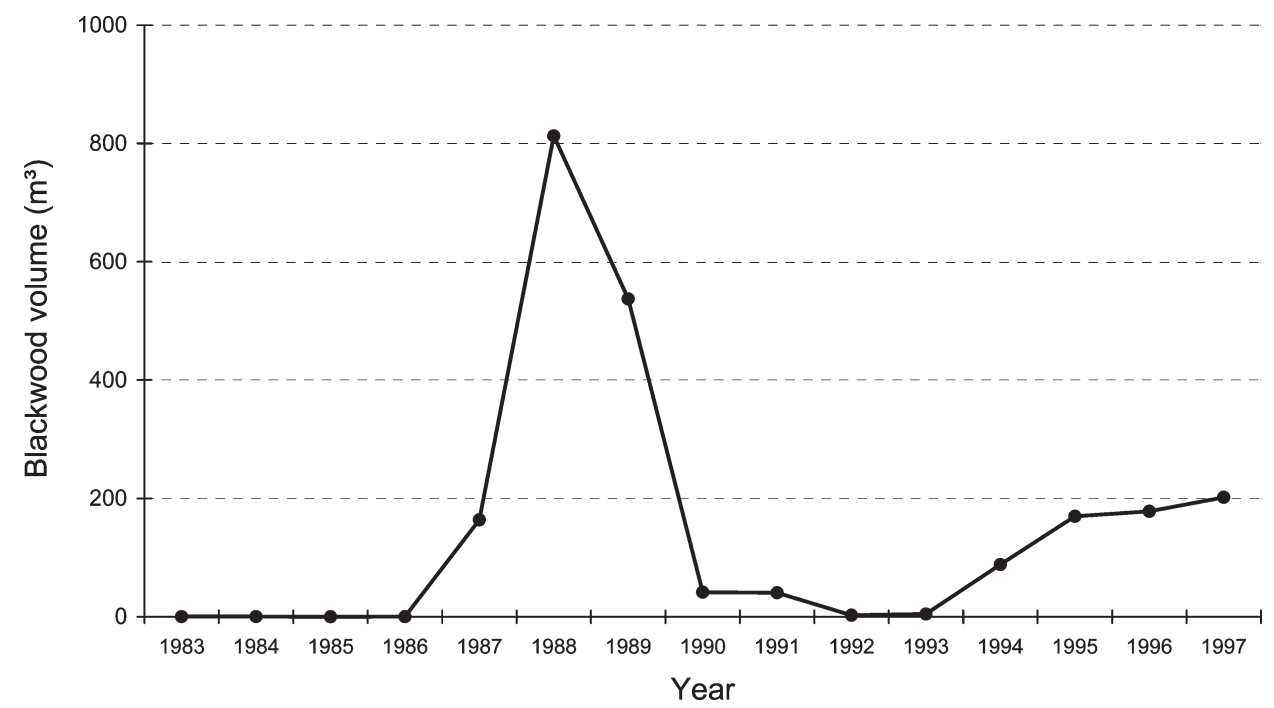

Fig. 1 Harvesting licenses for African Blackwood granted in Kilwa District, Tanzania, 1983-1997. 
worth of $1.7 \mathrm{~m}^{3} \mathrm{ha}^{-1}$ for the same Mitarure area in which I worked (Malimbwi et al., 2000), although they did include all harvestable stems and branches in their calculations. However my sample size is larger than that of Malimbwi et al. (2000) and Puhakka (1991) was working from secondary data that might have been manipulated by harvesters to reduce the apparent number of trees felled.

Multiple stems in miombo trees are often the result of vegetative regeneration from old root-stock or fire damage during the juvenile phase (Chidumayo, 1997), and therefore the greater prevalence of multi-stemmed trees could indicate areas that were disturbed in the past. However burned plots were distributed relatively evenly throughout the study area, and were not noticeably nearer habitation than other sample plots. Multistemmed blackwood is rarely suitable for sawmills as the stems are not thick enough to make billets.

The absence of any relationship between adult and juvenile blackwood suggests that regeneration is either occurring from old root stock or from well-dispersed seed. Juveniles were more than twice as likely to be found in more open areas than where canopy cover was significant, suggesting that light or absence of competition are important for regeneration, and supporting the hypothesis that blackwood may be a pioneer species (Ball et al., 1998).

The use of blackwood for firewood contrasts with the situation in Mikumi National Park, where rangers (who possibly have better quality cooking pots) frequently gather dead blackwood for firewood (Hawkins et al., 1995), but does agree with responses from other villages in Lindi region (Bevan \& Harrison, 2003). The high level of redundancy probably explains the low importance that local people appeared to attach to the tree. It did not appear to play a particularly important role in their daily lives and there are ready alternatives were it to become locally extinct. Only the medicinal properties of the leaves and bark for use during childbirth are unsubstitutable, but saplings and small trees can supply this demand. Villagers did not think local extinction would affect them significantly. This is similar to the situation found by Bevan \& Harrison (2003) further west in Nachingwea District, the most important district for blackwood harvesting. My overall impressions concur with Bevan \& Harrison (2003) that lack of ownership of either the trees or land contributes to a certain indifference on the part of local people to the fate of blackwood or the forest environment.

The inability of the foresters to enforce current regulations is a major disincentive to obtaining licences. Lack of transport means they are often dependent on the loggers for transport, and at other times will measure logs for licensing when they are brought back to the forestry office; certainly I saw many stumps without an official mark, and none with.

Blackwood is not in any immediate danger of biological extinction, but illegal harvesting, land clearance, and poor fire management could make it commercially unviable in the near future, as has already happened in Kenya (Cunningham, 1998). Local experts do not believe current exploitation levels are sustainable, but this has yet to be assessed systematically. Blackwood plantations are not economically feasible because of the long rotation time (Gregory et al., 1999), and therefore conservation in the wild and management of a sustainable harvest is vital if blackwood is to survive as a commercial timber. A nitrogen-fixing species that regenerates easily from root-suckers, blackwood has no conflict with most agricultural crops and could therefore be maintained on farms (Ball et al., 1998). In the instance of south-eastern Tanzania, the case for conservation is made more urgent by the recent completion of the bridge over the River Rufiji. The human population is expected to increase, and although local foresters anticipate a rise in illegal logging of all tree species they lack sufficient resources to combat this threat.

Blackwood meets all the criteria of Bowen-Jones \& Entwistle (2002) for flagship species (Table 2). However,

Table 2 Evaluation of blackwood against the criteria of Bowen-Jones \& Entwistle (2002) for flagship species.

\begin{tabular}{|c|c|}
\hline Criterion & Blackwood assessment \\
\hline 1. Geographical status & $\begin{array}{l}\text { Typical of the area; national tree of } \\
\text { Tanzania }\end{array}$ \\
\hline 2. Conservation status & $\begin{array}{l}\text { Common in the area and hence an } \\
\text { effective local ambassador for } \\
\text { conservation }\end{array}$ \\
\hline 3. Ecological role & $\begin{array}{l}\text { Nitrogen fixer; possible pioneer } \\
\text { species }\end{array}$ \\
\hline 4. Recognition & $\begin{array}{l}\text { Tree distinctive and easily } \\
\text { recognized by local people }\end{array}$ \\
\hline 5. Existing usage & $\begin{array}{l}\text { Not a subject of existing } \\
\text { conservation initiatives }\end{array}$ \\
\hline 6. Charisma & $\begin{array}{l}\text { Outward appearance is } \\
\text { emphatically non-charismatic, } \\
\text { but carvings and use in musical } \\
\text { instrument give it considerable } \\
\text { charisma by association }\end{array}$ \\
\hline 7. Cultural significance & $\begin{array}{l}\text { Carving tradition; one of the most } \\
\text { important species in the area for } \\
\text { local culture }\end{array}$ \\
\hline 8. Positive associations & $\begin{array}{l}\text { Used for a variety of purposes, plus } \\
\text { income from assisting loggers }\end{array}$ \\
\hline 9. Traditional knowledge & $\begin{array}{l}\text { High local awareness of the species } \\
\text { and its uses }\end{array}$ \\
\hline 10. Common names & $\begin{array}{l}\text { Indigenous names such as mugembe } \\
\text { (from its use as a hoe) have no } \\
\text { negative connotations, and } \\
\text { emphasize its usefulness }\end{array}$ \\
\hline
\end{tabular}


there are three factors in particular that together make blackwood an excellent flag-ship species for conservation. (1) Its use in musical instruments should facilitate fund-raising. (2) Its status as the national tree of Tanzania and its cultural significance arouse government and popular interest. (3) Its high economic value allows flexibility to vary levies without causing price distortions. It is for these reasons that blackwood has been adopted as a focal species of Fauna \& Flora International's SoundWood programme (SoundWood, 2004). The programme believes that many musicians would be prepared to pay a premium, or 'conservation tax', for instruments made from well managed sources, using Forest Stewardship Council-style certification. Tourists buying carvings may be similarly prepared to pay extra, although regulation of this market to ensure the validity of claims would be much harder.

Miombo is a species-rich ecosystem and its mammalian fauna requires large ranges. Consequently, for conservation of biodiversity to be effective, large contiguous areas of land must be safeguarded (Chidumayo, 1997). Even if the reserve system was enforced, fragmentation would have significant impact on the integrity of the protected areas, and therefore a compelling argument would need to be found to justify conservation of the forest on public lands. The poverty of the region is such that even an extra TSh 400,000 (US \$400) in annual village income could encourage the involvement of local people in the conservation of the woodlands. For example, I found $1.03 \mathrm{~m}^{3} \mathrm{ha}^{-1}$ of harvestable blackwood in one particular area with abundant blackwood. Allowing for only $20 \%$ of that in a more typical area, if a village were to receive 30\% of the licence fee for a $1 \%$ annual harvest quota within the village bounds (conservatively estimated at $100 \mathrm{~km}^{2}$ ), then they would receive TSh 420,000 (US \$420) a year into village funds. This may not be feasible everywhere, but in areas of high blackwood stocks it could prove a valuable source of income. The current policy of the Tanzanian government is broadly in favour of such arrangements in principle (MNRT, 1998) but of the many existing community forest management plans in Tanzania, all focus on the unreserved species for which a licence to fell is not required.

Community-based conservation is now the dominant narrative in Africa and yet the public face of conservation as presented by non-governmental organizations remains firmly attached to flagship mammal species. African blackwood is a species that could change this. Its high economic value and cultural significance both within Tanzania and internationally make it a suitable flagship species to justify conservation of its habitat on a large scale. Simple economic analysis suggests that community-based resource management could offer a good chance of achieving this. There remain challenges to overcome before practical conservation could take place, and apparent local indifference to the fate of the species would need to be considered. If these challenges can be met then blackwood could be used as an economic key to conserve as managed areas large tracts of miombo woodland, not through a system of forest reserves, but with a more inclusive strategy of sustainable exploitation of the region's natural resources. The Mpingo Conservation Project $(\mathrm{MCP}, 2004)$ is developing practical, community-based conservation initiatives along the lines outlined here, and establishing a long-term monitoring and research programme.

\section{Acknowledgements}

The research presented was carried out as part of the Tanzanian Mpingo 98 expedition of students from Cambridge University and the Sokoine University of Agriculture. I would particularly like to thank my co-leader Anne-Marie Gregory, the members and sponsors of the expedition, and people of Migeregere for their hospitality. My thanks also to Guy Norton for the initial inspiration, Sara Oldfield for continuing advice and encouragement, and our principal sponsor the Panton Trust.

\section{References}

ABCP (2004) African Blackwood Conservation Project.

Http:/ / www.blackwoodconservation.org [accessed 29 April 2004]

Ball, S.M.J., Smith, A.S., Keylock, N.S., Manoko, L., Mlay, D., Morgan, E.R., Ormand, J.R.H. \& Timothy, J. (1998) Tanzanian Mpingo 96. Final Report. Unpublished Report, Mpingo Conservation Project, Fauna \& Flora International, Cambridge, UK.

Bevan, L.J.V. \& Harrison, P.J. (2003) Mpingo '99. Full Report. Unpublished Report, Mpingo Conservation Project, Fauna \& Flora International, Cambridge, UK.

Bowen-Jones, E. \& Entwistle, A. (2002) Identifying appropriate flagship species: the importance of culture and local contexts. Oryx, 36, 189-195.

Campbell, B.M., Frost, P.G.H. \& Byron, N. (1996) Miombo woodlands and their use: overview and key issues. In The Miombo in Transition: Woodlands and Welfare in Africa (ed. B.M. Campbell), pp. 1-10. Center for International Forestry Research, Bogor, Indonesia.

Chidumayo, E.N. (1997) Miombo Ecology and Management. An Introduction. Stockholm Environment Institute, Stockholm, Sweden.

Cunningham, A.B. (1998) Ecological Footprint of the Wooden Rhino: Depletion of Hardwoods for the Carving Trade in Kenya. Http:/ / ftp.rbgkew.org.uk/peopleplants/regions/kenya/ hardwood.htm [accessed 14 August 1999].

Desanker, P.V., Frost, P.G.H., Frost, C.O., Justice, C.O. \& Scholes, R.J. (1997) The Miombo Network. Framework for a Terrestrial Transect Study of Land-use and Land-cover Change in the Miombo Ecosystems of Central Africa,. Unpublished Report. International Geosphere-Biosphere Programme, Stockholm, Sweden. 
Gregory, A.-M., Ball, S.M.J. \& Eziefula, U.E. (1999) Tanzanian Mpingo ‘98. Unpublished Report. Mpingo Conservation Project, Fauna \& Flora International, Cambridge, UK.

Haule, K.S., Johnsen, F.H. \& Maganga, S.L.S. (2002) Striving for sustainable wildlife management: the case of Kilombero Game Controlled Area, Tanzania. Journal of Environmental Management, 66, 31-42.

Hawkins, D.M., Lyaruu, H.V. \& Norton, G.W. (1995) Dalbergia melanoxylon in Mikumi National Park, Tanzania. In Towards Conservation and Responsible Use of Dalbergia Melanoxylon, pp. 44-51. Fauna \& Flora International, Cambridge, UK.

Högberg, P. (1986) Nitrogen-fixation and nutrient relations in savanna woodland (Tanzania). Journal of Applied Ecology, 23, 675-688.

Jenkins, M., Oldfield, S. \& Aylett, T. (2002) International Trade in African Blackwood. Unpublished Report. Fauna \& Flora International, Cambridge, UK.

Lewis, L.A. \& Berry, L. (1988) African Environments and Resources. Unwin Hyman, Boston, USA.

Lovett, J. (1987) Mpingo - the African blackwood. Swara, 10, $27-28$.

Lovett, J. (1988) Tree of the month: Dalbergia melanoxylon. Miombo, 2, 3

Malimbwi, R.E., Luoga, E.J., Hofstad, O., Mugasha, A.G. \& Valen, J.S. (2000) Prevalence and standing volume of Dalbergia melanoxylon in coastal and inland sites of southern Tanzania. Journal of Tropical Forest Science, 12, 336-347.

Marshall, N. (1995) Assessing the volume of trade. In Towards Conservation and Responsible Use of Dalbergia Melanoxylon, pp. 16-22. Fauna \& Flora International, Cambridge, UK.

MNRT (Ministry of Natural Resources and Tourism) (1998) National Forest Policy. Ministry of Natural Resources and Tourism, Dar es Salaam, Tanzania.

Moore, K. \& Hall, J.E. (1987) Report of a Mission to Assess the Management and Conservation of Dalbergia melanoxylon, or the Mpingo, in Tanzania. Unpublished Report. United Nations Environment Programme, Nairobi, Kenya.

MCP (2004) The Mpingo Conservation Project. Http:/ / www.mpingoconservation.org [accessed 28 April 2004].

Nshubemuki, L. (1994) Recent progress in silviculture research on Dalbergia melanoxylon in Tanzania. In Dalbergia: Proceedings of An International Workshop (eds S.B. Westley \& J.M. Roshetko), pp. 48-57. Nitrogen Fixing Tree Association, Hawaii, USA.

Puhakka, M. (1991) Inventory of Dalbergia melanoxylon (mpingo) in the Mtwara Region: Present State of Resources and Perspectives for its Sustainable Use in the Future. Unpublished Report. Turku-Mtwara Friendship Association, Turku, Finland.

SoundWood (2004) SoundWood. Http:// www.soundwood.org [accessed 29 April 2004].

White, F. (1983) The Vegetation of Africa. A Descriptive Memoir to Accompany the UNESCO/AETFAT/UNSO Vegetation Map of Africa. UNESCO, Paris, France.

Williams, P.H., Burgess, N.D. \& Rahbek, C. (2000) Flagship species, ecological complementarity and conserving the diversity of mammals and birds in sub-Saharan Africa. Animal Conservation, 3, 249-260.

\section{Biographical sketch}

Steve Ball founded the Mpingo Conservation Project in 1995 and has led and organized a number of research expeditions to Tanzania. He has also worked in Brazil and has a particular interest in sustainable forestry as a conservation tool. 